\title{
Cellular and molecular mechanisms in the pathogenesis of severe pulmonary hypertension
}

\author{
N.F. Voelkel, R.M. Tuder
}

Cellular and molecular mechanisms in the pathogenesis of severe pulmonary hypertension. N.F. Voelkel, R.M. Tuder. (CERS Journals Ltd 1995.

ABSTRACT: Chronic pulmonary hypertension leads to structural alterations of the lung vessels. The pathophysiology of this remodelling process is still poorly understood. Furthermore, the structural damage of the lung vessels limits the clinical success of vasodilator treatment. Given a genetic susceptibility, shear stress and inflammation are the principal pathogenetic factors involved in lung vessel remodelling.

In this overview, we compared the lung vascular histology of patients with unexplained pulmonary hypertension, scleroderma, or acquired immune deficiency syndrome (AIDS)-associated pulmonary hypertension. We demonstrate the presence of inflammatory cells ( $\mathrm{T}$ - and B-lymphocytes and macrophages) in plexiform lesions and discuss the potential role of growth factors (platelet-derived growth factor (PDGF), transforming growth factor- $\beta$ (TGF- $\beta$ ) and vascular endothelial growth factor (VEGF) in pulmonary hypertensive remodelling.

Ultimately, we need to develop an in-depth understanding of the key mechanisms of gene expression and signalling pathways, which transduce signals generated from increased chronic shear stress (or from chronic hypoxia) and lead to vascular injury and repair.

Eur Respir J., 1995, 8, 2129-2138.
Pulmonary Hypertension Center, Depts of Medicine and Pathology, University of Colorado Health Sciences Center, Denver, CO. USA.

Correspondence: N.F. Voelkel

Pulmonary and Critical Care Division

(Box C-272)

University of Colorado Health Sciences

Center

4200 East Ninth Avenue

Denver

CO 80262

USA

Keywords: Endothelial cell proliferation growth factors

pulmonary hypertension

pulmonary vascular remodelling

Received: February 201995

Accepted for publication March 201995
Chronic pulmonary hypertension leads to structural alterations of the lung circulation, commonly called pulmonary vascular remodelling [1-5]. Whereas pulmonary hypertension $(\mathrm{PH})$ may develop at some point in the natural history of most forms of heart or lung disease, mortality attributed directly to severe pulmonary hypertension is relatively infrequent. It is believed that a genetic predisposition must be present to permit the development of severe pulmonary hypertension [6], where the pulmonary artery pressure is at or above the systemic pressure level. For the most part, this conviction stems from the consideration of two facts: firstly, there are patients with a familial form of primary pulmonary hypertension (PPH), and secondly, the incidence of severe pulmonary vascular disease in a large group of patients who, in the 1970s, took appetite depressants was small [7]. Likewise, more recent observations regarding the development of severe pulmonary hypertension in paticnts with acquired immune deficiency syndrome (AIDS) leads to the same conclusion: i.e. a relatively small number of patients with plexogenic pulmonary hypertension has so far been described when compared with the overall population of patients with AIDS [8, 9].

Given such a required genetic susceptibility, we hypothesize that the principal factors which (perhaps in combination) lead to drastic pulmonary vascular remodelling are shear stress, chronic hypoxia, and inflammation (cytokines) [10-14]. Each of these factors, individually or acting in concert, may bring about a change in the phenotype of the pulmonary endothelial and vascular smooth muscle cells. We postulate a hypertensive cell phenotype [1], which is characterized by a phenotypic switch of the cells towards an enhanced capacity for proliferation, secretion of matrix proteins, and - regarding the endothelial cells - the development of a procoagulant surface. Recently, shear stress response elements [15] have been identified in the sequence of genes encoding important growth factors which might also be candidate growth factors for pulmonary vascular remodelling. It is now being appreciated that chronic hypoxia can alter the expression of particular genes; for example, the gene coding for vascular endothelial growth factor (VEGF) or for the mitogeninducible cyclo-oxygenase-2 [16, 17], and that hypoxia can elaborate the hypoxia-inducible factor (HIF), which appears to be a key protein binding to recognition sites of genes known for their susceptibility to regulation by changes in oxygen tension (like erythropoietin) [18-20]. Lastly, products of inflammatory cells (cytokines, such as interleukin-1, tumour necrosis factor, and interferons) can modify the expression of growth factors in vascular cells. Thus, a picture is emerging which is based upon the concept of gene regulation, and also on the concept of cell-cell interactions. 
In the following, we wish to address several questions concerning the cellular and molecular events implicated in the phenotypic switch of the vascular cell. Which are the (relevant) pulmonary cells that contribute to the vascular remodelling? How important is the endothelial cell and how important are extravascular cells in the pathogenesis of chronic pulmonary hypertension? What are the relevant growth factors, cytokines, and how do they contribute to the development of a pulmonary hypertensive cell phenotype?

We shall attempt to provide evidence for the importance of the endothelial cell in the pulmonary vascular proliferative process and also to establish the pertinent histological features, which suggest common pathogenetic principles which are operating in many or all forms of severe pulmonary hypertension.

It is clear that endothelial cells have the capacity to release growth-promoting substances, such as plateletderived growth factor (PDGF), insulin-like growth factor (IGF), anti-adhesive molecules, such as prostacyclin, and that the endothelial cell is also a target cell equipped with specialized receptors (e.g. receptors for VEGF, which transmit signals resulting in cell proliferation). We have been impressed with the degree of endothelial cell proliferation, which is present in the vessels of patients with severe primary pulmonary hypertension [13]. Whereas plexiform lesions are present in many forms of severe pulmonary hypertension, there are no definitive diagnostic lesions. LOYD et al. [21] demonstrated in the familial form of PPH an assortment of vascular lesions and, from case to case, a varying distribution of intima sclerosis, plexiform lesions, and in situ thrombosis.

We take the view that the vascular lesions can be defined by their maturation, i.e. one can distinguish between early and late lesions and actively proliferating lesions compared with burned out scar tissue. We propose that the pulmonary vascular remodelling of severe chronic pulmonary hypertension is driven to a large degree by angiogenesis factors, and further propose that inflammatory mechanisms are of critical importance in the development of the characteristic pulmonary hypertension lesions.

\section{Comparative histological assessment of lesions in the lungs from patients with unexplained PPH, scleroderma and AIDS}

Pulmonary hypertension is characterized by profound structural alterations in the affected vessels. Severe chronic pulmonary hypertension occurs because of constriction of resistance vessels (as in chronic hypoxia) which leads to media hypertrophy, or because of obliteration of vessels through in situ thrombosis or intima cell proliferation. Based on the morphology of pulmonary hypertensive vessels, several authors have described a component of vascular smooth muscle proliferation/ hypertrophy, subintimal fibrosis, thrombosis and plexogenic vessels in pulmonary hypertension $[13,21,23]$. Such a morphological approach is necessary, but limits the understanding of the early events related to alterations of pulmonary vessels, since vascular remodelling seems to represent an advanced stage in the natural history of pulmonary hypertension. In addition, because of the limitation of such a strictly morphological approach, the previous pathophysiological studies on pulmonary hypertension have focused on the vascular wall cells to the exclusion of the neighbouring parenchyma and airway cells.

Immune histology and in situ hybridization techniques are valuable tools to sort out participating cells, cell products, and the activity of candidate genes in the pathophysiology of pulmonary hypertension. We have demonstrated that, in the plexogenic type of pulmonary hypertension, the pulmonary arteries with concentric obliterative and plexiform lesions contain an increased number of endothelial cells as assessed by immune histology (fig. 1) [13]. Therefore, these lesions can be viewed as an expression of abnormal angiogenesis occurring in the pulmonary vessels. However, the common occurrence of the obliterative and the plexiform lesions along the same mediumsized pulmonary artery raises questions regarding the topographical and temporal relationship between these two lesions. The obliterative lesion may represent an upstream event in the process of pulmonary vascular remodelling in pulmonary hypertension. As such, this lesion has a dramatic impact on blood flow in the diseased pulmonary vessels. On the other hand, the plexiform lesions are probably haemodynamically irrelevant but may represent markers of the severity of vascular disease and manifestation of pulmonary revascularization. It is possible that the concentric obliterative lesion evolves from proliferated endothelial cells, the proliferation being triggered by local thrombosis, increased shear stress and continuous release or production of growth factor.

\section{Inflammatory cells in pulmonary hypertension: source and target of vascular cell growth factors}

Inflammatory cells (T-, B-lymphocytes and macrophages) have recently been described surrounding plexiform lesions in primary pulmonary hypertension and in pulmonary hypertension associated with scleroderma and human immunodeficiency virus (HIV) infection (fig. 2) [24]. Although the precise role of these perivascular inflammatory cells remains uncertain, vascular growth factors, such as VEGF [25-29] and transforming growth factor beta (TGF- $\beta$ ) $[3,30]$, act on inflammatory cells (similar to the action of cytokines) [25]. Furthermore, inflammatory cells themselves may constitute a source of VEGF, PDGF and TGF- $\beta$, further amplifying the extent of blood vessel remodelling. Macrophages can produce growth factors, such as VEGF and PDGF, and TGF- $\beta$ and VEGF can stimulate monocyte migration through endothelial cell monolayers, thus, potentially attracting increased numbers of monocytes/macrophages in the close proximity of remodelled pulmonary vessels. T-lymphocytes associated with hypertensive pulmonary vessels (fig. 2) may be related to local production of a cytokine or to a local immune ressponse to antigens. The interactions of T-lymphocytes with the pulmonary endothelial cells may cause release of PDGF, as can be demonstrated when virally-infected endothelial cells are co-incubated with 

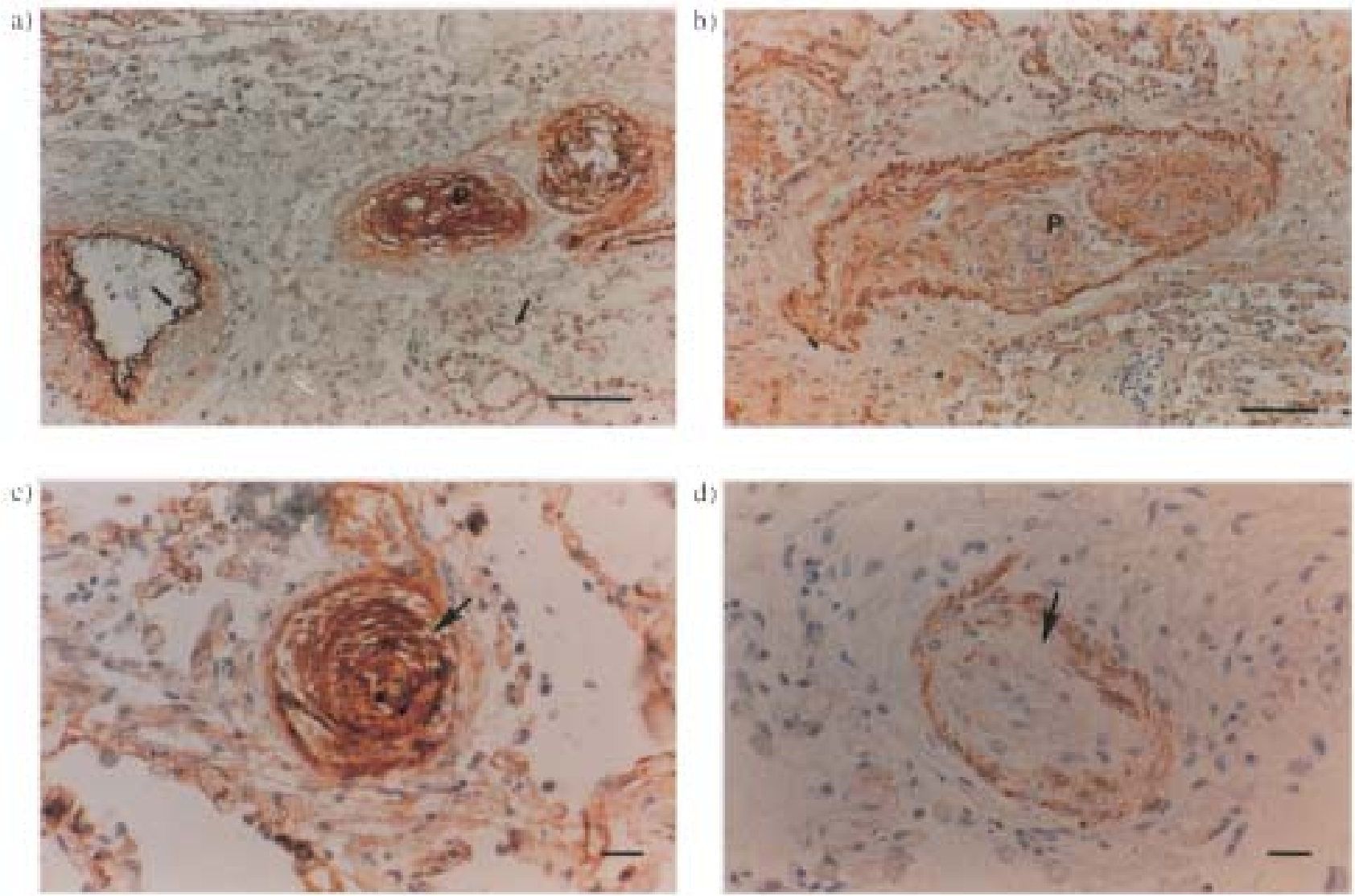

Fig. 1. - Immunostaining for: a) factor VIII r.Ag; and b) muscle specific antigen of a plexiform lesion (P) in a patient with primary pulmonary hypertension. Note the increased expression of factor VIII by endothelial cells, with no expression of muscle antigen. Factor VJJ positive endothelial cells line normal blood vessels as a monolayer, as seen in the segment of the vessel in the left lower comer of (a) and in pulmonary vessels (arrows). The concentric obliterative lesion in a case of scleroderma-associated pulmonary hypertension exhibits increased numbers of endothelial cells that are: c) factor VIII r.Ag positive; and d) muscle specific antigen negative. r.Ag: receptor antigen. (Internal scale bar=100 pm).

T-lymphocytes in vitro [31]. Cytokines can also influence pulmonary levels of vascular growth factors.

Interestingly, HUMBERT et al. [14] reported elevated serum interleukin-1 (IL-1) levels in PPH patients. IL-1, besides its potent proinflammatory action on endothelial cells, monocytes and T-lymphocytes, also mediates smooth muscle cell growth. An indirect mechanism, involving PDGF or TGF- $\beta$ synthesis and autocrine/paracrine action on smooth cells, accounts for IL-1 induced smooth muscle cell growth. IL-1 also stimulates production of coll agen by fibroblasts, fibroblast growth, and activates the cycle-oxygenase pathway. In recent animal studies, we could show that interleukin-1 receptor antagonist (IL-lra) treatment inhibited the development of inflammation but not hypoxia-associated pulmonary hypertension [32]. The cellular structures of hypertensive pulmonary arteries as described above are also present in pulmonary hypertension associated with systemic sclerosis and HIV infection (fig. 2). In summary, the process of pulmonary vas cular lar remodelling in pulmonary hypertension involves endothelial cells, vascular smooth muscle and adventitia fibroblast proliferation, and, perhaps, extravascular cells.

\section{Mediators and growth factors in severe pulmonary hypertension and pulmonary vascular remodelling}

Upon appropriate stimulation, inflammatory cells, platelets and vessel wall cells can produce proteins which can affect vascular permeability, cell adhesion and release of secondary mediators, or directly affect cell growth Uptake of serum proteins, such as insulin-like growth factor (IGF) [33], and of circulating peptides, like angiotensin or bradykinin, into the vessel wall layers may be facilitated when the vessel is injured. In the human pulmonary hypertensive vessels, several of these factors may work together and cause cell hypertrophy, hyperplasia and angiogenesis. Figure 3 depicts the putative effects of growth factors on pulmonary vascular cells. Although a theoretical rationale exists to invoke several of these growth promoting factors in pulmonary vascular remodelling, there is still a paucity of data in human pulmonary hypertension $[3,27]$.

PDGF may act as a universal inducer of vascular cell proliferation. Although early studies failed to reveal PDGF receptors on large vessel endothelial cells, PDGF induces proliferation of microvascular endothelial cells 
a)

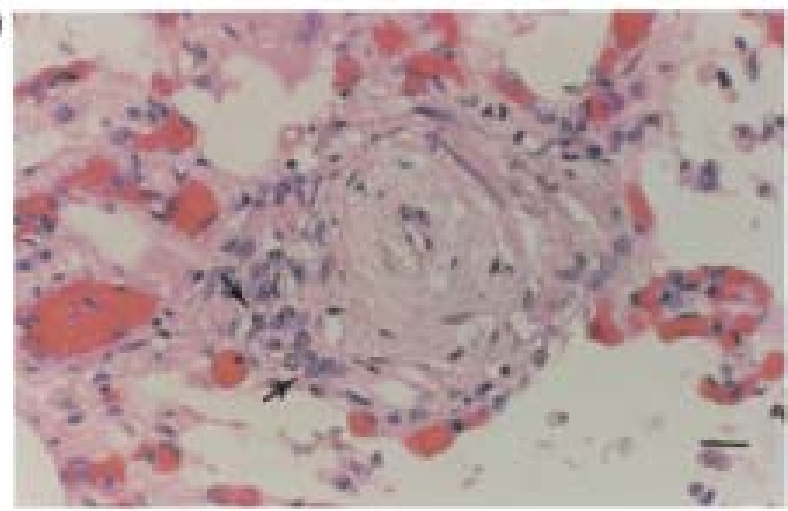

c)

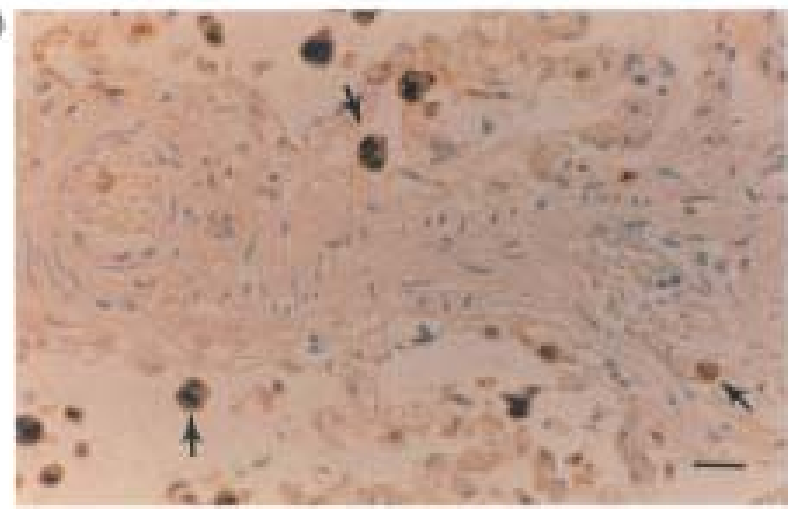

e)

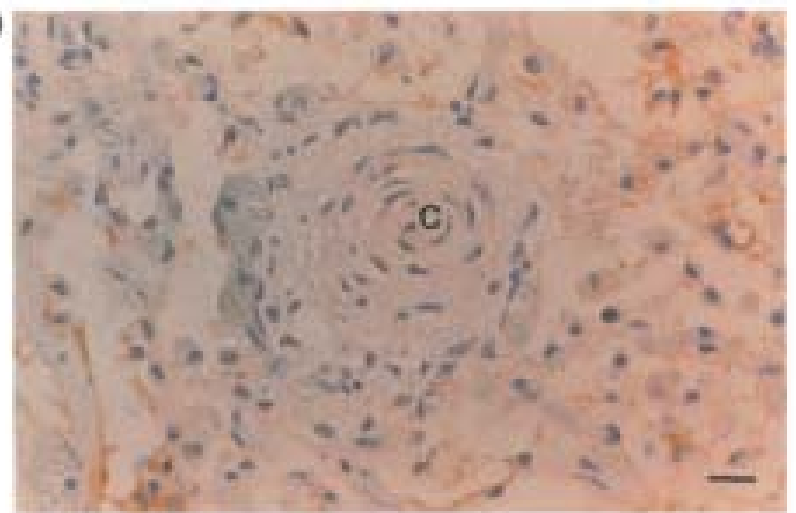

b)

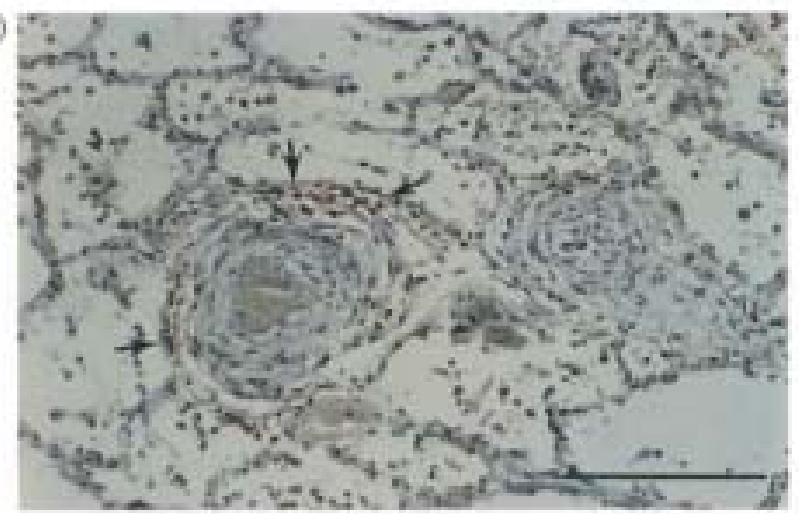

d)

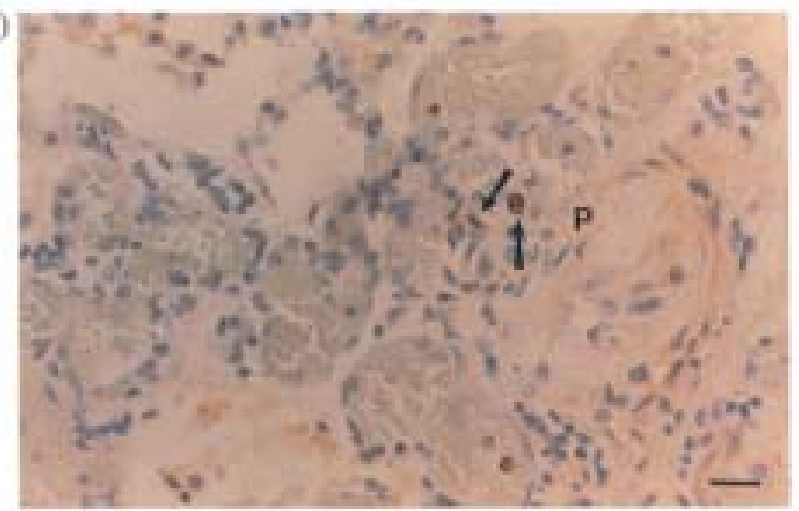

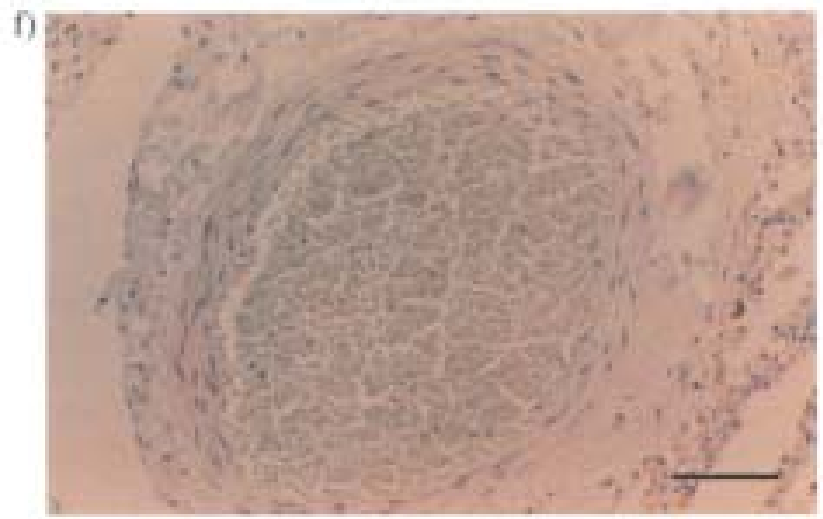

Fig. 2. - a) Haematoxylin and eosin stained pulmonary artery in a case of pulmonary hypertension associated with scleroderma. Note that intimal obliteration due to intimal thickening. The blood vessel is surrounded by lymphonuclear cells (arrow). The remnining lung tissue did not show evidence of airway inflammation. b) T-cell immunostaining (anti-CD45 antibody) showing increased numbers of T-cells seen clustering around and infiltrating remodelled pulmonary arteries in a case of primary pulmonary hypertension (arrows). c) Macrophages are also a major component of the perivascular inflammatory infiltrate. as seen in a plexiform lesion in an human immunodeficiency virus (HIV)-associated pulmonary hypertension (arrows). d) In the same case as (c), there is evidence of endothelial cell proliferation, as assessed by immunostaining for the proliferation-related antigen Ki-67. in the plexiform lesion (P) (MJB-I monoclonal antibody) (arrow). e) There is no immunostaining for Ki-67 in the concentric obliterative lesion (c). thus suggesting that this lesion does not have evidence of ongoing endothelial cell proliferation. f) Normal pulmonary arteries and arterioles do not express Ki-67, thus suggesting that endothelial cell proliferation in normal blood vessels is almost nonexistent. (Internal scale bar=100 pm). 


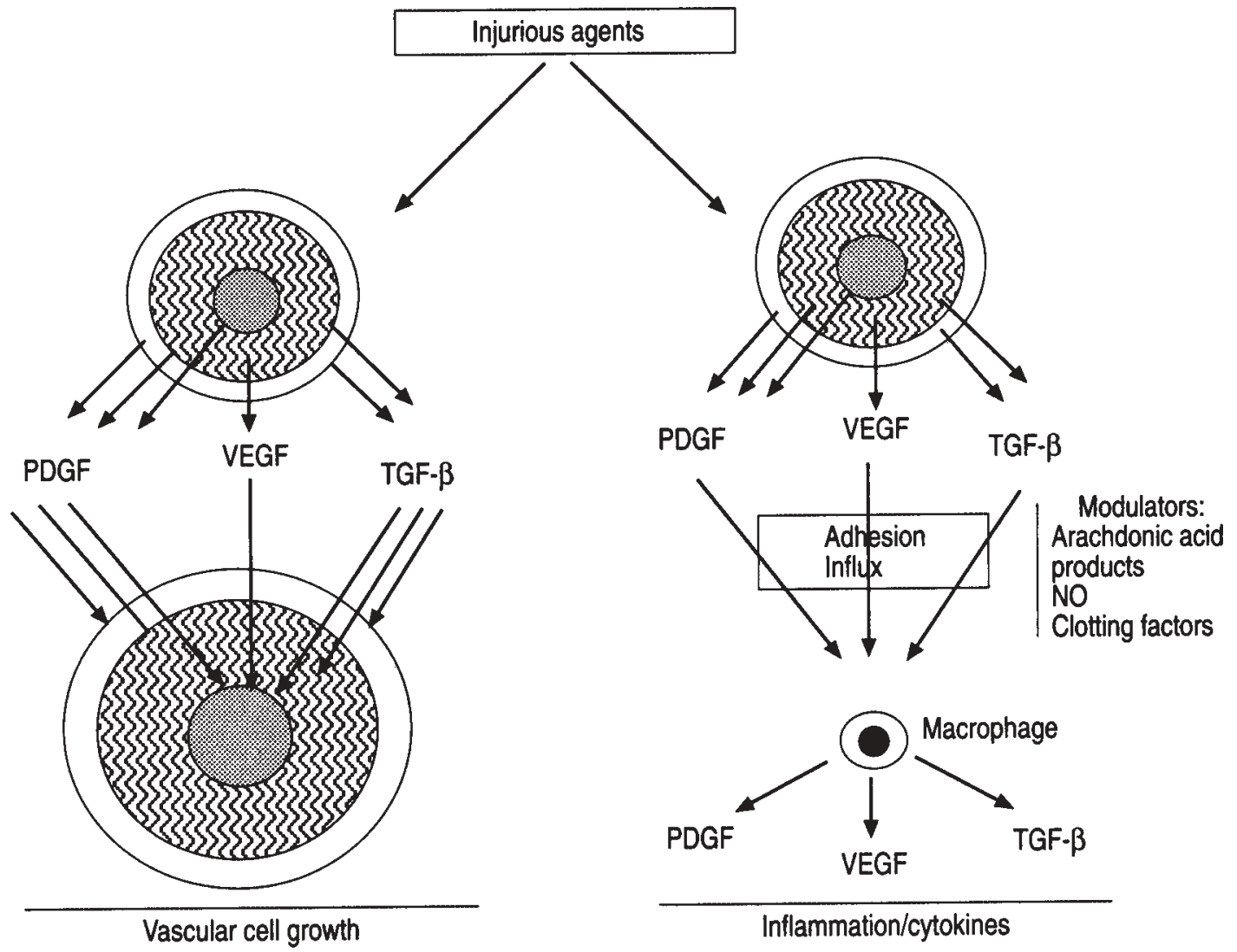

Fig. 3. - Autocrine and paracrine mechanisms of vascular growth factor actions. Factors may be generated by the cells of the vascular media and find receptors on the endothelium triggering endothelial cell growth (left). Growth factors also affect the activity (chemotaxis and adhesion) of inflammatory cells and act on inflammatory cells to release cytokines. PDGF: platelet-derived growth factor; VEGF: vascular endothelial growth factor; TGF- $\beta$ : transforming growth factor- $\beta$.

in vitro. Furthermore, PDGF can trigger VEGF production by fibroblasts overexpressing protein kinase $\mathrm{C}$.

TGF- $\beta$ is directly involved in extracellular matrix synthesis, including synthesis of fibronectin and collagen. Recently, BOTNEY et al. [2,3] demonstrated TGF- $\beta$ expression in muscular pulmonary arteries in PPH and in normal pulmonary arteries. There was an apparent increase in level of TGF- $\beta$ expression in pulmonary hypertension when compared to the normal lung. Recent studies demonstrated that TGF- $\beta$ messenger ribonucleic acid (mRNA) is present in human vascular lesions and that vascular transfection with TGF- $\beta$ results in vascular intimal and medial thickening. Increased cell numbers and an increase of the matrix proteins seem to account for the increased intimal and medial thickening present in transfected segments of porcine iliac arteries. In addition, TGF- $\beta$ stimulates angiogenesis in in vivo models of arterial gene transfection. Growth factors that affect vascular cell growth are probably interacting in a network, as do cytokines. TGF- $\beta$ enhances growth of cultured smooth cells via secretion of PDGF. In addition, TGF- $\beta$ may influence endothelial cell proliferation via VEGF synthesis (figs. 3 and 4) [26]. VEGF may be important in pulmonary hypertension [27]. The lung contains abundant VEGF mRNA and upregulates VEGF protein levels and transcription upon exposure to hypoxia [16]. We have previously localized VEGF transcripts to bronchiolar cells and alveolar macrophages

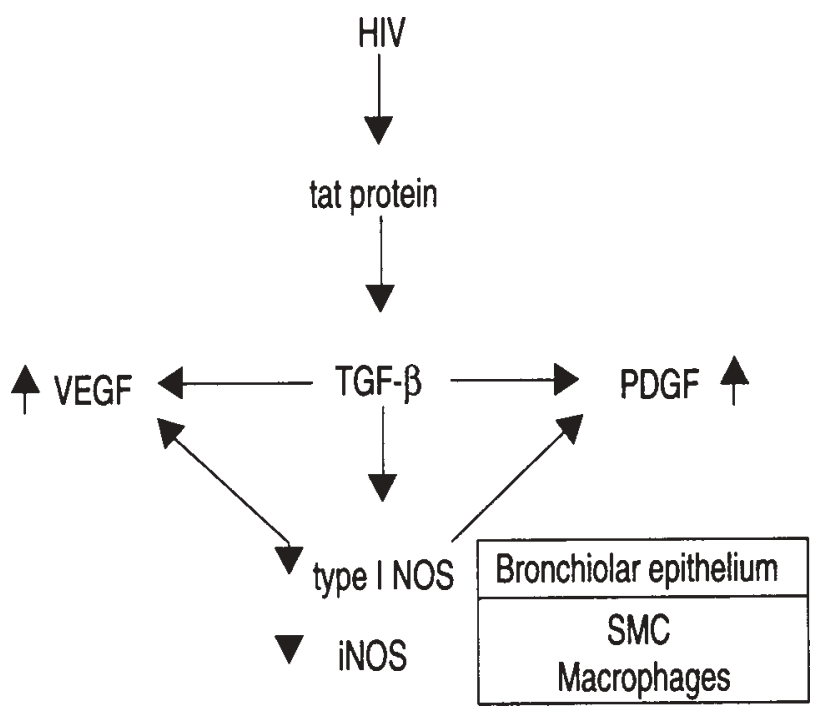

Fig. 4. - Paradigm which integrates the activity of a retroviral protein (tat) which is produced by macrophages. The tat protein can generate the growth factor TGF- $\beta$ which in turn may stimulate gene expression and production of other growth factors. The activity of these in situ generated factors appears to be under the control of nitric oxide $(\bullet N O)$. HIV: human immunodeficiency virus; SMC: smooth muscle cell; NOS: nitric oxide synthase; iNOS: inducible form of nitric oxide synthase. For further abbreviations see legend to figure 3 . 
present in the vicinity of plexiform lesions. VEGF protein expression, however, is localized both to the sites of VEGF synthesis as well as to endothelial cell sites of VEGF binding to its receptors. VEGF can, thus, promote endothelial cell proliferation and lead to enhanced vascular permeability. The action of VEGF in angiogenesis depends on the binding to the VEGF tyrosine-kinase type receptors Flt and $\operatorname{Kdr}[25,28]$. There is recent evidence that supports a major role for $\mathrm{Kdr}$ (or the murine equivalent Flk) in transducing the cellular signal after VEGF binding to endothelial cells [34]. We found that hypoxia, besides enhancing VEGF synthesis, also upregulates VEGF receptor mRNA expression [16].

\section{Arachidonic acid and metabolites}

Lipid mediators derived via the cyclo-oxygenase pathway of the lipoxygenase pathways might be involved in the control of pulmonary hypertensive vascular remodelling [35]. CHRISTMAN et al. [36] found increased thromboxane and decreased prostacyclin $\left(\mathrm{PGI}_{2}\right)$ metabolites in the urine samples from patients with PPH. In a neonatal model of severe, hypoxia-induced pulmonary hypertension, a decrease in lung vascular $\mathrm{PGI}_{2}$ synthesis has been found [35], and inhibitors of 5-lipoxygenase inhibited the development of pulmonary hypertension in animal models [37, 38]. Northern blot analysis performed with tissue obtained at the time of lung transplantation from a patient with PPH shows increased expression of the mitogen-inducible cyclo-oxygenase-2 gene (fig. 5). Impaired endothelial cell function [39, 40] (or alteration of the endothelial cell phenotype) could explain a decrease in lung $\mathrm{PGI}_{2}$ production, platelet activation [41], and increased thromboxane synthesis. A decrease in local $\mathrm{PGI}_{2}$ availability is likely to promote cell growth and vascular remodelling.

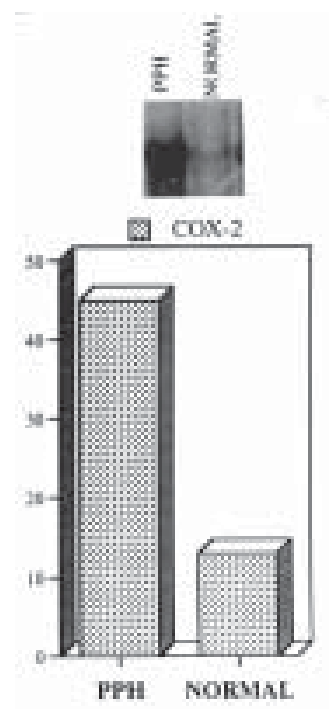

Fig. 5. - Cyclo-oxygenase (COX)-2 mRNA expression (arbitary units) in a patient with primary pulmonary hypertension $(\mathrm{PPH})$ and normal lung (upper panel). There is an approximately 4-fold increase in COX-2 expression in PPH lung when compared with normal lung as assessed by scanning densitometry of the COX-2 band after correction for loading with the glyceraldehyde-phosphate dehydrogenase mRNA in both experimental samples.

\section{Nitric oxide}

Impaired pulmonary vascular endothelial cell function probably includes impaired nitric oxide formation or nitric oxide metabolism. It is now clear that endogenously produced $\bullet$ NO plays a major role in the control of lung vessel tone $[42,43]$. Whether a defect in lung vascular or lung macrophage $\bullet \mathrm{NO}$ production occurs in human pulmonary hypertensive disease is less clear. Control of growth factor gene regulation (PDGF, VEGF) (fig. 4) by $\bullet$ NO has recently been reported [44].

\section{The procoagulant-hypoflbrinolytic state of pulmonary hypertension}

Organized and recanalized thrombi are frequently detected in the vessels from patients with a variety of pulmonary hypertensive disorders [45]. In situ thrombosis may be due to low blood flow, high blood flow (shear stress), viral infection and release and procoagulant factors. The coagulation and fibrinolytic abnormalities which underlie pulmonary in situ thrombosis are not well understood, and the role of von Willebrand factor in pulmonary hypertension is unclear [46, 47]. Increased circulating levels of von Willebrand factor may reflect endothelial injury [48]. Recently, Rothman et al. [49] showed that thrombin and PDGF lead to hypertrophy and hyperplasia of pulmonary artery smooth muscle cells, respectively. Both agents caused in increased expression of immediate early genes, like egr-1,c-fos, and $c$-jun.

\section{Matrix protein synthesis and protease activity in pulmonary vascular remodelling}

In severe pulmonary hypertension, there is a large amount of collagen and elastin deposited throughout the vessel wall. Pentachrome staining (fig. 1) demonstratesthe adventitia fibrosis, which undoubtedly contributes to the loss of vascular reactivity of the hypertensive vessels. BOTNEY et al. [2] recently found procollagen in $20-100 \%$ of the small pulmonary arteries from patients with PPH using immune staining techniques. Release of proteolytic enzymes in the vessel wall produce free elastin and other matrix proteins, which could serve as chemotactic factors. The vascular smooth muscle cell may be central in the "organization" of elastase release, in the binding of elastin to elastin-binding proteins on smooth muscle cells, in the increased migration of smooth muscle cells and in the secretion of matrix proteins $[5,50]$. Both TNF and IL-1 have been shown to regulate smooth muscle cell fibronectin gene expression [51]. Angiotensin II (fig. 6 ) and aldosterone and their fibrogenic potential have also recently been examined [52]. Both elastase inhibitors and angiotensin converting enzyme (ACE) inhibitors have been shown to inhibit pulmonary vascular remodelling in animal models of chronic pulmonary hypertension [50, 53]. The role of matrix proteins in hypertensive pulmonary vascular remodelling was also the topic of a recent symposium [54]. 


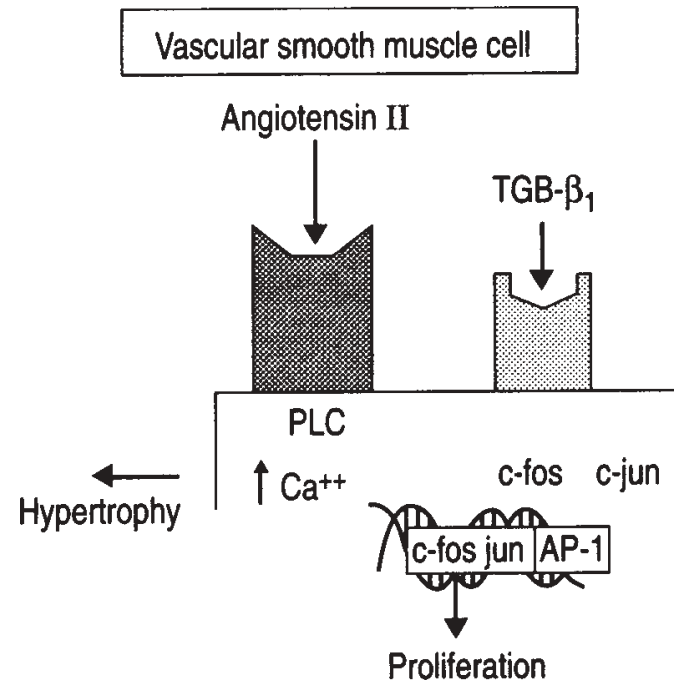

Fig. 6. - Angiotensin II, perhaps generated in situ in the vessel wall, can cause vascular smooth muscle cell (VSMC) hypertrophy or proliferation depending on the presence or absence of synergistic factors like transforming growth factor- $\beta_{1}$, (TGF- $\left.\beta_{1}\right)$. Angiotensin II by itself causes an increase in intracellular calcium via activation of the phospholipase C (PLC). This translates into cell hypertrophy. Angiotensin II induces the growth associated proto-oncogenes $c$-myc, $c$-fos, and $c$-fos, The protein products of these immediate early genes may be intermediaries of signal transduction in cell growth and differentiabon.

\section{Signalling pathways involved in pulmonary vascular remodelling}

The conceptual framework for the forces and interactions which govern pulmonary vascular remodelling is shown schematically in figure 7 . Stretch and tension deform the cell membranes and affect the cytoskeleton [55-59]. The signal transduction involves changes in membrane potential, opening or close of ion channels [60-64], changes in cytosolic calcium [65-67], and second messengers like cyclic adenosine monophosphate (cAMP) and cyclic guanosine monophosphate (cGMP) $[68,69]$. Activation of protein kinases and phosphorylation reactions are part of the cell response, which includes alteration of gene expression $[69,70]$. It has been recognized that nitric oxide plays an important role in gene expression $[16,44,71]$, and that alternatively growth factors can affect the induction of the nitric oxide synthase [72]. Genes which are expressed in response to hypoxia include those encoding erythropoietin [18-20, 73], interleukin-1 $\alpha$, PDGF, endothelin, ornithine decarboxylase and, as mentioned, VEGF [16] and cyclo-oxygenase 2 (COX-2). A hypoxia-inducible nuclear factor (HIF) has been shown to bind to a site in the erythropoietin gene enhancer. Both the HIF and its recognition sequence are common components of a general response to hypoxia.

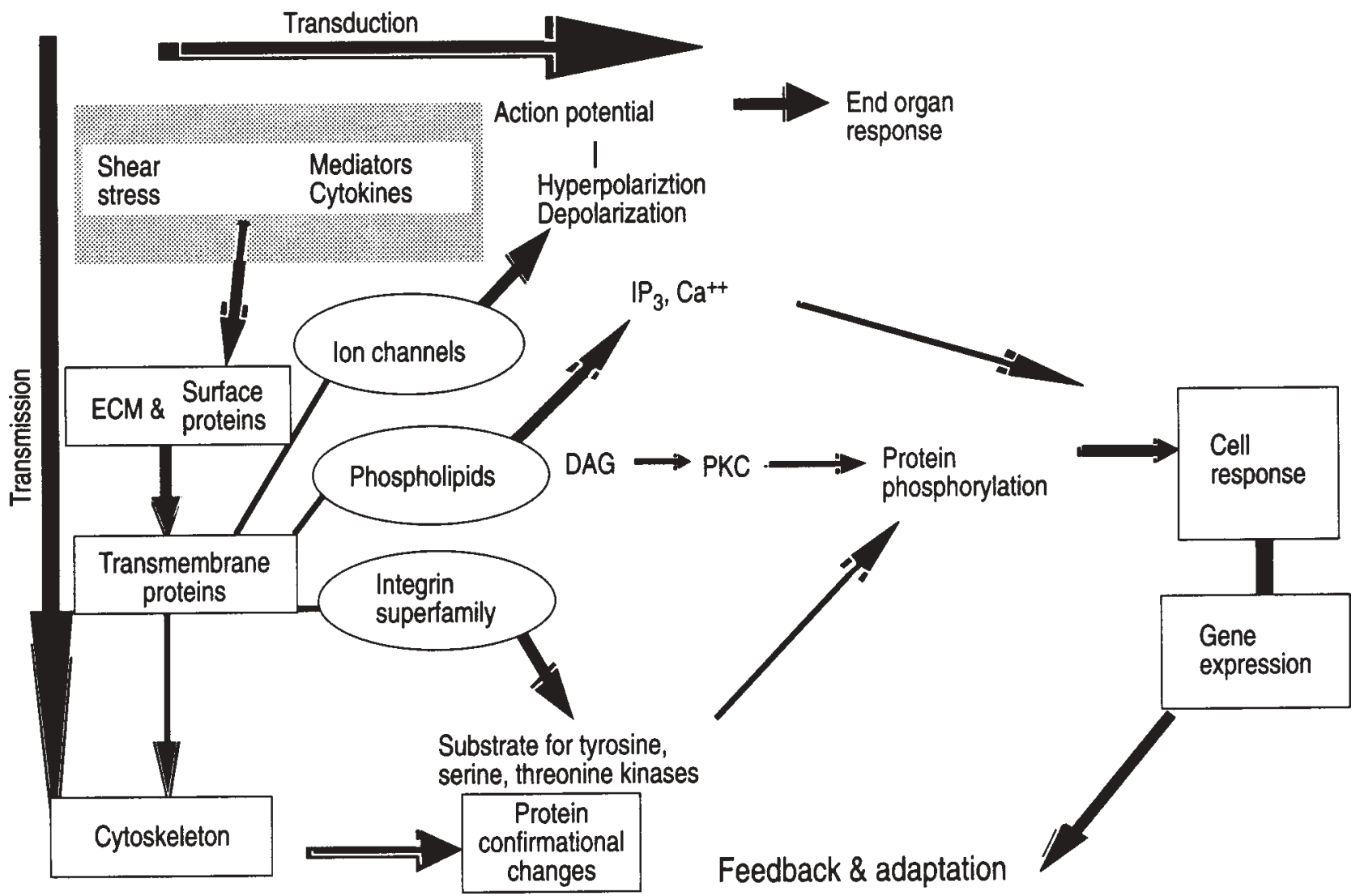

Fig. 7. - Transduction and transmission of signals which are received at the vascular cell surface. Shear stress may open ion channels, alter the electrical membrane potential, deform cytoskeletal proteins, initiate phosphorylation reactions. Cytokines released by inflammatory cells act on vascular cell receptors and transmit their signal via inositol triphosphate ( $\mathrm{IP}_{3}$ ), diacylglycerol (DAG) and protein kinase $\mathrm{C}$ (PKC). Expression of immediate early genes may initiate adaptive cell responses, i.e. cell growth or matrix protein synthesis. 
The question now is: which are the relevant steps in the regulation which are also susceptible to therapeutic intervention?

In conclusion, the cell biology and molecular pathways which are critically involved in pulmonary vascular remodelling are still in their infancy. It is apparent to us that endothelial cell proliferation is an important feature of PPH and in severe PH associated with systemic sclerosis. In contrast, vascular remodelling in interstitial fibrosis and chronic obstructive lung disease does not show such prominent involvement of endothelial cells. Thus, an element of neovasculization is present in PPH. Embolic transport of tumour cells and implantation of such tumour cells in small lung arterioles can trigger the formation of plexiform pulmonary arteries [74]. It is unclear, at present, which growth factor(s) is (are) critically implicated or whether there is an imbalance of the local growth factor involvement. We consider that cytokines and lipid mediators [75] (which are locally produced) are involved in the remodelling process of progressive PPH. They can affect cell growth, matrix protein synthesis and the coagulation/anticoagulation balance [76, 77]. Local cytokine action is part of the inflammatory aspect of $\mathrm{PPH}$, which has not yet received adequate investigative attention.

\section{References}

1. Mecham RP, Whitehouse IA, Wrenn DS, et al. Smooth muscle-mediated connective tissue remodeling in pulmonary hypertension. Science 1987; 237: 423-426.

2. Botney MD, Bahadori L, Gold LI. Vascular remodeling in primary pulmonary hypertension. Am J Pathol 1994; 144: 286-295.

3. Botney M. Vascular remodeling in primary pulmonary hypertension: what role for transforming growth factorbeta. Semin Respir Crit Care Med 1994; 15:215-225.

4. Tuder RM. Plexiform lesions in primary pulmonary hypertension may represent an abnormal form of angiogenesis. SeminRespirCritCare Med 1994; 15:207-214.

5. Rabinovitch M. Elastase, remodeling of extracellular matrix, and pulmonary hypertension. Semin Respir Crit Care Med 1994; 15: 199-205.

6. Voelkel NF, Weir EK. Etiologic mechanisms in primary pulmonary hypertension. In: Weir EK, Reeves JT, eds. Pulmonary Vascular Physiology, Lung Biopsy in Health and Disease. Vol. 38. New York, Marcel Dekker, 1989; pp. 513-541.

7. Gurtner HP. Chronische pulmonale Hypertonie vaskulären Ursprungs, plexogene pulmonale Arteriopathie und der Appetizügler Aminorex. Nachlese zu einer Epidemie. Schweiz Med Wschr 1985; 115: 782-789.

8. Mette SA, Palevsky HI, Pietra GG, et al. Primary pulmonary hypertension in association with human immunodeficiency virus infection. Am Rev Respir Dis 1992; 145: 1196-1200.

9. Ruchelli ED, Nojadera G, Rutstein RM, Rudy B. Pulmonary veno-occlusive disease: another vascular disorder associated with human immunodeficiency virus infection. Arch Pathol Lab Med 1994; 118: 664-666.

10. Reeves JT, Voelkel NF. Mechanisms of chronic pulmonary hypertension: basic considerations. In: Wagenvoort CA, ed. Pulmonary Circulation. Amsterdam, Elsevier, 1989; pp. 27-39.

11. Ono S, Voelkel NF. Inflammation and pulmonary hypertension during hypoxia. In: Ueda G, Reeves JT and Sekiguchi M, eds. High Altitude Medicine. Matsumoto, Shinshu University Press, 1994; pp. 347-354.

12. Voelkel NF. Role of platelet-derived growth factor and other growth factors in inflammation. In: Henson PM, Murphy RC, eds. Handbook of inflammation. Vol. 6. Mediators of inflammatory Process. New York, Elsevier, 1989; pp. 269-299.

13. Tuder RM, Groves B, Badesch DB, Voelkel NF. Exuberant endothelial cell growth and elements of inflammation are present in plexiform lesions of pulmonary hypertension. Am J Pathol 1994; 144: 275-285.

14. Humbert M, Monti G, Brenot F, Emilie D, et al. Serum IL-1, IL-6 and TNF- $\alpha$ in primary pulmonary hypertension. Am J Respir Crit Care Med 1994; 149 (4): A747.

15. Resnick N, Collins T, Atkinson W, Bonthron DT, Dewey F, Gimbrone MA. Platelet-derived growth factor B chain promoter contains a cis-acting fluid shear stress responsive element. Proc Natl Acad Sci USA 1993; 90: 45914595.

16. Tuder RM, Flook B, Voelkel NF. Increased gene expression for VEGF and the VEGF receptors Kdr/Flk and Flt in lungs of chronically hypoxic rats. J Clin Inv 1995; 95: 1798-1807.

17. Chida M, Voelkel NF. Acute but not chronic hypoxia upregulates lung cyclo-oxygenase-2 gene via prostacyclin. Am J Respir Cell Mol Biol 1994; (submitted).

18. Wang GL, Semenza GL. General involvement of hypoxiainducible factor 1 in transcriptional response to hypoxia. Proc Natl Acad Sci USA 1993; 90: 4304-4308.

19. Costa-Giomi P, Caro J, Weinman R. Enhancement by hypoxia of human erythropoietin gene transcription in vitro. $J$ Biol Chem 1990; 265: 10185-10188.

20. Semenza GL, Wang GL. A nuclear factor induced by hypoxia via de novo protein synthesis binds to the human erythropoietin gene enhancer at a site required for transcriptional activation. Mol Cell Biol 1992; 12: 5447-5454.

21. Loyd JE, Atkinson JB, Pietra CG, Virmani R, Newman JH. Heterogenicity of pathologic lesions in familial primary pulmonary hypertension. Am Rev Respir Dis 1988; 38: 952-957.

22. Caslin AW, Heath D, Madden B, Yacoub M, Gosney JR, Smith P. The histopathology of 36 cases of plexogenic pulmonary arteriopathy. Histopathology 1990; 16:9-19.

23. Wagenvoort CA, Wagenvoort N. Pathology of pulmonary hypertension. J. Wiley et al., eds. New York, Elsevier, 1977.

24. Cool C, Tuder RM, Voelkel NF. Plexiform pulmonary lesions in scleroderma and AIDS: Is there a common pathogenesis? Am J Pathol 1994; (submitted).

25. Shen H, Clauss M, Ryan J, et al. Characterization of vascular permeability factor/vascular endothelial growth factor receptors on mononuclear phagocytes. Blood 1993; 10: 2767-2773.

26. Pertovaara L, Kaipainen A, Mustonen T, et al. Vascular endothelial growth factor is induced in response to transforming growth factor- $\beta$ in fibroblastic and epithelial cells. J Biol Chem 1994; 269: 6271-6274.

27. Tuder RM, Voelkel NF. Vascular endothelial growth factor (VEGF) induction in primary pulmonary hypertension. J Cell Biochem 1994; 18A: 330.

28. Shweiki D, Itin A, Neufeld G, Gitay-Goren H, Keshet E. Patterns of expression of vascular endothelial growth 
factor (VEGF) and VEGF receptors in mice suggest a role in hormonally regulated angiogenesis. J Clin Invest 1993; 91: 2235-2243.

29. Goldberg MA, Schneider TJ. Similarities between the oxygen-sensing mechanisms regulating the expression of vascular endothelial growth factor and erythropoietin. $J$ Biol Chem 1994; 269: 4355-4359.

30. Perkett EA, Badesch DB, Roessler MD, Stenmark KR, Meyrick B. Insulin-like growth factor I and pulmonary hypertension induced by continuous air embolization in sheep. Am Rev Respir Dis 1991; 143: A185.

31. Tuder RM, Weinberg A, Bates TO, Hoeper MM, Zhang L, Voelkel NF. Tat-protein of HIV enhances inflammatory cell binding and PDGF levels in CMV-infected endothelial cells. Circulation 1994; 90(4): 1-417.

32. Voelkel NF, Tuder RM. Interleukin-1 receptor antagonist inhibits pulmonary hypertension induced by inflammation. NY Acad Sci 1994; 3: 1711.

33. Dempsey EC, Stenmark KR, McMurtry IF, O'Brien RF, Voelkel NF, Badesch DB. Insulin-like growth factor I and protein kinase $\mathrm{C}$ activation stimulate pulmonary artery smooth muscle cell proliferation through separate but synergistic pathways. J Cell Physiol 1990; 144: 159-165.

34. De Vries C, Escobedo JA, Ueno H, Houck K, Ferrara N, Williams LT. The fms-like tyrosine kinase, a receptor for vascular endothelial growth factor. Science 1992; 255: 989-991.

35. Voelkel NF, Badesch DB, Zapp LM, Stenmark KR. Impaired prostacylin synthesis of endothelial cells derived from hypertensive calf pulmonary arteries. In: Widimsky J, Herget J, eds. Pulmonary Blood Vessels in Lung Disease. Basel, Karger, 1990; pp. 63-69.

36. Christman BW, McPherson CD, Newman JH, et al. An imbalance between the excretion of thromboxane and prostacyclin metabolites in pulmonary hypertension. $N$ Engl J Med 1992; 327: 70-75.

37. Morganroth ML, Stenmark KR, Morris KG, et al. Diethylcarbamazine inhibits acute and chronic hypoxic pulmonary hypertension in awake rats. Am Rev Respir Dis 1985; 131 : 488-492.

38. Voelkel NF, McDonnell TJ, Chang SW, Bugnitz M, Westcott JY, Stenmark KR. The future for drugs affecting lipoxygenase pathway in the treatment of pulmonary hypertension and ARDS. IBC Tech Serv 1987; 1-11.

39. Loscalzo J. Endothelial dysfunction in pulmonary hypertension. N Engl J Med 1992; 327: 117-119.

40. Dinh-Xuan AT, Higenbottam TW, Clelland CA, et al. Impairment of endothelium-dependent pulmonary artery relaxation in chronic obstructive lung disease. $N$ Engl J Med 1991; 324: 1539-1547.

41. Rostagno C, Prisco D, Boddi M, Poggesi L. Evidence for local platelet activation in pulmonary vessels in patients with pulmonary hypertension secondary to chronic obstructive pulmonary disease. Eur Respir J 1991; 4 147-151.

42. Isaacson TC, Hampl V, Weir EK, Nelson DP, Archer SL. Increased endothelium-derived NO in hypertensive pulmonary circulation of chronically hypoxic rats. J Appl Physiol 1994; 76: 933-940.

43. Eddahibi S, Adnot S, Carville C, Blouquit Y, Raffestin B. $\mathrm{L}$-arginine restores endothelium-dependent relaxation in pulmonary circulation of chronically hypoxic rats. Am J Physiol 1992; 263: L194-L200.

44. Kourembanas S, McQuillan LP, Leung GK, Faller DV. Nitric oxide regulates the expression of vasoconstrictors and growth factors by vascular endothelium under both normoxia and hypoxia. J Clin Invest 1993; 92: 99-104.

45. Wagenvoort CA, Mulder GH. Thrombotic lesions in primary plexogenic arteriopathy. Chest 1993; 103: 844-849.

46. Geggel RL, Carvalho ACA, Hoyer LW, Reid LM. Von Willebrand factor abnormalities in primary pulmonary hypertension. Am Rev Respir Dis 1987; 135: 294-299.

47. Rabinovitch M, Andrew M, Thom $\mathrm{H}$, et al. Abnormal endothelial factor VIII associated with pulmonary hypertension and congenital heart defects. Circulation 1987; 76: $1043-1052$.

48. Jones DK, Perry EM, Grosso MA, Voelkel NF. Release of von Willebrand factor antigen (vWF Ag) and eicosanoids during acute injury to the isolated rat lung. Am Rev Respir Dis 1992; 145: 1410-1415.

49. Rothman A, Wolner B, Button D, Taylor P. Immediateearly gene expression in response to hypertrophic and proliferative stimuli in pulmonary arterial smooth muscle cells. J Biol Chem 1994; 269: 6399-6404

50. Botney MD, Kaiser LR, Cooper JD, et al. Extracellular matrix protein gene expression in atherosclerotic pulmonary arteries. Am J Pathol 1992; 140: 357-364.

51. Claussell N, Rabinovitch M. Upregulation of fibronectin synthesis by interleukin- $1 \beta$ in coronary artery smooth muscle cells is associated with the development of the postcardiac transplant arteriopathy in piglets. J Clin Invest 1993; 92: $1850-1858$

52. Weber H, Taylor DS, Molloy CJ. Angiotensin II induces delayed mitogenesis and cellular proliferation in rat aortic smooth muscle cells. J Clin Invest 1994; 93: 788-798.

53. Zakheim RM, Mattioli L, Molteni A, Mullis KB, Bartley J. Prevention of pulmonary vascular changes of chronic alveolar hypoxia by inhibition of angiotensin Iconverting enzyme in the rat. Lab Invest 1975; 33: 57-61.

54. Bishop JE, Evans TW, Laurent GJ. The pulmonary vasculature in health and disease. Eur Respir Rev 1993; 3: 16.

55. Davies PF. How do vascular endothelial cells respond to flow? NIPS 1989; 4: 22-25.

56. Davies PF, Tripathi SC. Mechanical stress mechanisms and the cell. Circ Res 1993; 72: 239-245.

57. Wang N, Butler JP, Ingber DE. Mechanotransduction across the cell surface and through the cytoskeleton. Science 1993; 260: 1124-1127.

58. Riley DJ, Thakker-Varia S, Poiani GJ, Tozzi CA. Effects of mechanical forces on lung vascular remodeling. Semin Respir Crit Care Med 1994; 15: 175-189.

59. Voelkel NF. Pulmonary hypertension: from phenomenology to a molecular understanding of disease mechanisms. In: Weir EK, et al., eds. Ion Flux in Pulmonary Vascular Control. New York, Plenum Press, 1993; 1-14.

60. Cooke JP, Rossitch E, Andon NA, Loscalzo J, Dzau VJ Flow activates an endothelial potassium channel to release an endogenous nitrovasodilator. J Clin Invest 1991; 88: 1663-1671.

61. Rodman DM, Voelkel NF. Regulation of vascular tone. In: Crystal RG, West JB, et al., eds. The lung: Scientific Foundations. New York, Raven Press, 1991; pp. 11051119.

62. Post JM, Hume JR, Archer SL, Weir EK. Direct role for potassium channel inhibition in hypoxic pulmonary vasoconstriction. Am J Physiol 1992; 262: C882-C890.

63. Dubois J, Rouzaire-Dubois B. Role of potassium channels in mitogenesis. Prog Biophys Mol Biol 1993; 59: $1-21$.

64. Nilius B, Droogmans G. A role for $\mathrm{K}^{+}$channels in cell proliferation. NIPS 1994; 9: 105-109. 
65. Shen J, Luscinskas FW, Connolly A, Dewey CF, Gimbrone MA. Fluid shear stress modulates cytosolic free calcium in vascular endothelial cells. Am J Physiol 1992; 262: C384-C390.

66. Cornfield DN, Stevens T, McMurty IF, Abman SH, Rodman DM. Acute hypoxia increases cytosolic calcium in fetal pulmonary artery smooth muscle cells. Am $J$ Physiol 1993; 265: L53-L56.

67. Salvaterra CG, Goldman WF. Acute hypoxia increases cytosolic calcium in cultured pulmonary arterial myocytes. Am J Physiol 1993; 264: L323-L328.

68. Xu X, Star RA, Tortorici G, Muallem S. Depletion of intracellular $\mathrm{Ca}^{2+}$ stores activates nitric oxide synthase to generate cGMP and regulate $\mathrm{Ca}^{2+}$ influx. J Biol Chem 1994; 269: 12645-12653.

69. Arias J, Alberts AS, Brindle P, et al. Activation of cAMP and mitogen responsive genes relies on a common nuclear factor. Nature 1994; 370: 226-229.

70. Michel JB, Ordway GA, Richardson JA, Wlliams RS. Biphasic induction of immediate early gene expression accompanies activity-dependent angiogenesis and myofiber remodeling of rabbit skeletal muscle. J Clin Invest 1994; 94: 277-285
71. Peunova N, Enikolopov G. Amplification of calciuminduced gene transcription by nitric oxide in neuronal cells. Nature 1993; 364: 450-453.

72. Schini VB, Catovsky S, Schray-Utz B, Busse R, Vanhoutte $\mathrm{PM}$. Insulin-like growth factor I inhibits induction of nitric oxide synthase in vascular smooth muscle cells. Circ Res 1994; 74: 24-32.

73. Rondon IJ, MacMillan LA, Beckman BS, et al. Hypoxia upregulates the activity of a novel erythropoietin mRNA binding protein. J Biol Chem 1992; 266: 16594-16598.

74. Pfister SJ, Tuder RM. Plexogenic pulmonary arteriopathy in a case of adenocarcinoma of the prostate with tumor emboli to the lungs. Semin Respir Crit Care Med 1994; 15: 516-521.

75. Ono S, Westcott JY, Voelkel NF. PAF antagonists inhibit pulmonary vascular remodeling induced by hypobaric hypoxia in rats. J Appl Physiol 1992; 73: 1084-1092.

76. Welsh CH, Marlar RA, Hassell KL. Coagulation activation, fibrinolysis and severity of pulmonary hypertension. Am Respir Crit Care Med 1994; 149 (4): A746.

77. Henrikson KP. Thrombin as a hormonally-regulated growth factor in estrogen-responsive tissue. Semin Thrombos Hemostas 1992; 18: 53-59. 